\title{
Physico-Chemical Quality of Lake Kyoga at Selected Landing Sites and Anthropogenic Activities
}

\author{
Robert Ongom, Morgan Andama*, Ben Lukubye \\ Department of Biology, Faculty of Science, Mbarara University of Science and Technology, Mbarara, Uganda \\ Email: *amorgan@must.ac.ug, *andamamorgan@gmail.com
}

How to cite this paper: Ongom, R., Andama, M. and Lukubye, B. (2017) Physico-Chemical Quality of Lake Kyoga at Selected Landing Sites and Anthropogenic Activities. Journal of Water Resource and Protection, 9, 1225-1243. https://doi.org/10.4236/jwarp.2017.911080

Received: August 18, 2017

Accepted: October 17, 2017

Published: October 20, 2017

Copyright (c) 2017 by authors and Scientific Research Publishing Inc. This work is licensed under the Creative Commons Attribution International License (CC BY 4.0).

http://creativecommons.org/licenses/by/4.0/

\section{cc (i) Open Access}

\begin{abstract}
Lake Kyoga, one of the great African lakes in Uganda is facing an increasing pressure from human activities yet there is limited information on water quality of the lake. Therefore this study determined selected physico-chemical parameters of Lake Kyoga at some landing sites (Kayei, Acholi inn, Waitumba, Masindi port) and anthropogenic activities (boat dock, waste site, garden, fishing). The parameters included temperature, $\mathrm{pH}$, water flow rate, dissolved oxygen (DO), nitrite $\left(\mathrm{NO}_{2}^{-}\right)$and phosphate $\left(\mathrm{PO}_{4}^{-} \mathrm{P}\right)$. The American Public Health Association (APHA) and Water Watch Australia protocols, standard meters, Merck's rapid test kits and timing of a float were used to measure the parameters. The results showed that the mean temperature, $\mathrm{pH}, \mathrm{DO}, \mathrm{NO}_{2}^{-}$and $\mathrm{PO}_{4}-\mathrm{P}$ significantly $(\mathrm{p}<0.05)$ varied across the anthropogenic activities. On the other hand, only temperature, $\mathrm{pH}$ and flow rate varied significantly $(\mathrm{p}<0.05)$ across the landing sites. Lake Kyoga water flow rates were the fastest at Masindi port $(0.031 \mathrm{~m} / \mathrm{s})$ and the least in Waitumba $(0.021 \mathrm{~m} / \mathrm{s})$ governed by river inflow and surface vegetation cover. The mean $\mathrm{pH}(6.73-7.15)$ and $\mathrm{DO}$ $(10.15-13.50 \mathrm{mg} / \mathrm{l})$ of the lake at all the study sites were within the Environmental Protection Agency (EPA) standard values of $5.5-8.5$ and $\geq 9.0 \mathrm{mg} / \mathrm{l}$ respectively. These mean $\mathrm{pH}$ and $\mathrm{DO}$ values reflect more or less neutral waters which are equally well saturated with oxygen at all the landing sites. However, areas close to the waste sites had the least oxygen levels $(10.15 \mathrm{mg} / \mathrm{l})$ followed by gardens $(11.82 \mathrm{mg} / \mathrm{l})$ while fishing areas were the most saturated with oxygen $(13.50 \mathrm{mg} / \mathrm{l})$. On the other hand, temperature $\left(25.06^{\circ} \mathrm{C}-25.76^{\circ} \mathrm{C}\right)$ and $\mathrm{NO}_{2}^{-}(0.13-0.49 \mathrm{mg} / \mathrm{l})$ levels in the study sites were above EPA standards of $25^{\circ} \mathrm{C}$ and $\leq 0.03 \mathrm{mg} / \mathrm{l}$ respectively signifying warmer waters and sewage pollution at the sites. Fortunately, the $\mathrm{NO}_{2}^{-}$levels were within the EPA drinking water guideline of $0.5 \mathrm{mg} / \mathrm{l}$. The orthophosphates $\left(\mathrm{PO}_{4}-\mathrm{P}\right)$ were high-
\end{abstract}


est in the waste sites $(0.35 \mathrm{mg} / \mathrm{l})$, followed by gardens $(0.24 \mathrm{mg} / \mathrm{l})$ and least in the fishing areas $(0.12 \mathrm{mg} / \mathrm{l})$. However, phosphates in the form of $\mathrm{P}_{2} \mathrm{O}_{5}$ were higher than the EPA standard value $(0.5 \mathrm{mg} / \mathrm{l})$ at Kayei $(0.55 \mathrm{mg} / \mathrm{l})$ and Acholi inn $(0.55 \mathrm{mg} / \mathrm{l})$ landing sites as well as at waste sites $(0.80 \mathrm{mg} / \mathrm{l})$ and gardens $(0.55 \mathrm{mg} / \mathrm{l})$ pointing to high nutrient (phosphorus) input at these sites. The high concentrations of nitrites in Lake Kyoga at the investigated anthropogenic activities and landing sites plus phosphate amounts close to waste sites and gardens including Kayei and Acholi inn landing sites call for vigilance in protection of Lake Kyoga through optimized planning. Hence, National Environment Management Authority should ensure proper sewage management in Lake Kyoga catchment to avoid discharge of untreated sewage into the lake. The authority should also regulate waste dumping and cultivation around the lake so as to reduce nutrient (phosphorus) enrichment.

\section{Keywords}

Anthropogenic Activity, Lake Kyoga, Landing Site, Physico-Chemical Parameter

\section{Introduction}

Lake Kyoga is one of the African Great Lakes situated in Uganda, East Africa [1]. An estimated 9.3 million people live in Lake Kyoga Basin with $85 \%$ of the population mainly engaged in agriculture comprised of livestock farming and crop growing as their major industrial activity [2] [3]. Consequently, most of the watershed areas have been rapidly converted into agricultural land and rangelands [4]. For instance $48.5 \%$ of wetlands in the Lake Kyoga region were lost between 1994 and 2008 alone due to conversion to agriculture [5]. In addition, about 200,000 people are directly engaged in fishing [6] and the lake plays an important role for inland water transport [7]. Furthermore, most of the inhabitants get water for drinking and other domestic uses directly from the lake [8]. The above activities have resulted into the disappearance of vegetation as well as gully erosion in Lake Kyoga catchment causing pollution of the lake [9]. As the number of people and animals increased around Lake Kyoga, more waste from human activities and livestock has been discharged into the lake [10] leading to nutrient (mainly phosphorus and nitrogen) enrichment.

Unfortunately, Lake Kyoga is very vulnerable to the impacts of pollution [11] [12] [13]. The high nutrient enrichment has transformed the lake from mesotrophic to eutrophic conditions [14]. As a result, there has been an increased algal biomass and dominance by blue-green algae in Lake Kyoga indicating the deterioration of its quality [15] [16] [17]. With the increasing human population and associated activities in the Lake Kyoga catchment, water pollution problems are likely to rise hence there is a need for continuous monitoring. However, previous limnological investigations on Lake Kyoga are few and small in scope as compared to other African lakes and Lake Kyoga basin is the least studied of the 
Nile tributaries [18]-[23]. Hence this study determined the physico-chemical quality of Lake Kyoga at the most common anthropogenic activities (boat dock, waste site, garden and fishing areas) with high water pollution potential in selected landing sites within the lake basin.

\section{Materials and Methods}

\subsection{Location of Study Area}

Lake Kyoga (Figure 1 ) is located north of Lake Victoria (lat. $1^{\circ} 15^{\prime}-1^{\circ} 45^{\prime} \mathrm{N}$; long. $\left.31^{\circ} 31^{\prime}-33^{\circ} 31^{\prime} \mathrm{E}\right)$ at an altitude of $1100 \mathrm{~m}$ on the central African plateau. The Kyoga aquatic system is comprised of three major lakes namely Kyoga (1821 $\mathrm{km}^{2}$, length $\left.190 \mathrm{~km}\right)$, Kwania $\left(508 \mathrm{~km}^{2}, 105 \mathrm{~km}\right)$ and Bisinia [24]. Lake Kyoga is a shallow lake of about $3.6 \mathrm{~m}$ mean depth and the total surface area of open water of Kyoga lakes is about $2700 \mathrm{~km}^{2}$ [1]. The lakes lie within a 74,700 $\mathrm{km}^{2}$ Lake Kyoga catchment area with numerous wetlands in central Uganda [10] [25]. Lake Kyoga Catchment area falls in the larger River Nile Basin, stretching from the Great Lakes region (Burundi, Rwanda, The Democratic Republic of Congo, Tanzania, Uganda and Kenya) to North Africa [10]. The dense swamps that surround the shores of Lake Kyoga with an area coverage of $2000 \mathrm{~km}^{2}$ are mainly extensive mats of papyrus comprising of Cyperus papyrus [25] [26]. The largest inflow into Lake Kyoga comes from Lake Victoria through the Victoria Nile while Lake Kyoga drains out through the Kyoga Nile connecting to Lake Albert [10] [14]. Most of the rocks in Lake Kyoga basin are gneisses and granites [2] consisting mainly of feldspar and quartz. Feldspar is a group of silicate minerals comprising of $(\mathrm{Si}, \mathrm{Al}) \mathrm{O}_{4}$ linked with $\mathrm{K}, \mathrm{Na}$, and $\mathrm{Ca}$ and sometimes $\mathrm{Ba}$ ions while quartz consists of crystalline silica (silicon dioxide, $\mathrm{SiO}_{2}$ ) [27].

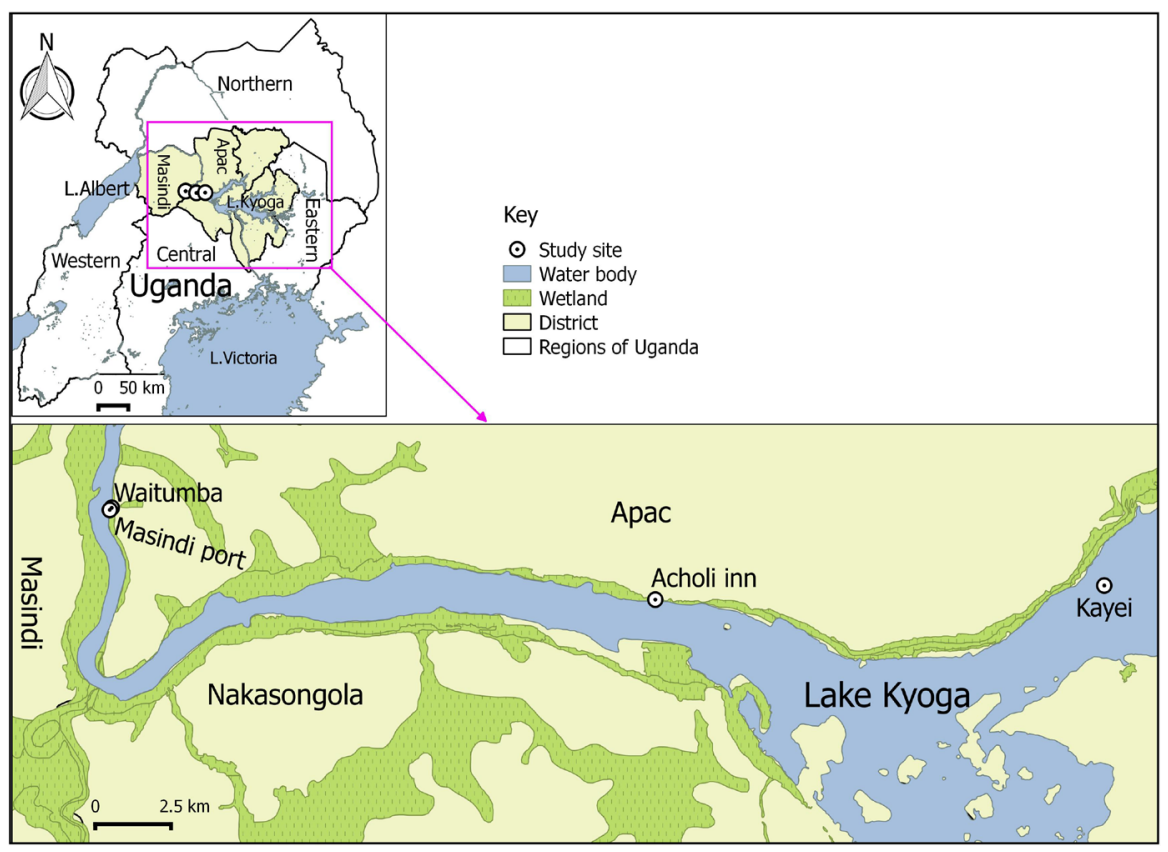

Figure 1. Map of Uganda showing Lake Kyoga and the location of the study sites. 
Lake Kyoga basin experiences a bi-modal rainfall distribution pattern with two peak rainfall periods in April/May and October/November while the rest of the months (March-November) have well-spread distribution of rainfall [23] [28]. The basin, however, receives low rainfall during December, January and February [28]. The mean annual rainfall in Lake Kyoga basin is $1294 \mathrm{~mm}$ [23].

Four landing sites (Figure 1) were thus purposively selected from Lake Kyoga including Waitumba at geographical coordinates $\left(1.6993^{\circ} \mathrm{N}, 32.0988^{\circ} \mathrm{E}\right)$, Masindi port $\left(1.6986^{\circ} \mathrm{N}, 32.0982^{\circ} \mathrm{E}\right)$, Acholi inn $\left(1.6726^{\circ} \mathrm{N}, 32.2601^{\circ} \mathrm{E}\right)$ and Kayei $\left(1.6767^{\circ} \mathrm{N}\right.$, $32.3934^{\circ} \mathrm{E}$ ) to investigate the contribution of associated anthropogenic activities; fishing, waste disposal, farming and transport (boat dock) to the physico-chemical quality of the lake.

\subsection{Sampling}

At each of the landing sites (Kayei, Acholi inn, Waitumba and Masindi port), water samples and on-site measurements were taken at every established anthropogenic activity (boat dock, waste site, garden and fishing areas). For temperature, $\mathrm{pH}$ and DO, 6 on-site measurements were each taken during the mid morning, afternoon and evening, totalling to 18 measurements for every parameter at each anthropogenic activity. On the other hand, only 6 water samples were obtained to determine nitrite and phosphate concentrations and 6 on-site flow rate measurements taken at each anthropogenic activity, all during the mid morning period. The water samples and measurements were taken at a distance of $10 \mathrm{~m}$ from one another in an area of about $2500 \mathrm{~m}^{2}$. All the water sampling and measurements were done in the months of December, 2015 and January, 2016.

\subsection{Determination of the Physico-Chemical Parameters}

\subsubsection{Dissolved Oxygen (DO) and Temperature}

Dissolved Oxygen and temperature were determined using a simple DO meter [29]. After rinsing the tip of the DO meter electrode with distilled water, it was then dipped into the water at the sampling points and left for some time until the readings stabilized. The stable DO and corresponding temperature values were then read and recorded.

\subsection{2. $\mathrm{pH}$}

The $\mathrm{pH}$ of the water samples was determined using a $\mathrm{pH}$ meter [30]. The $\mathrm{pH}$ meter was also dipped into the water at the sampling points and left for some time for the readings to stabilize. The stable $\mathrm{pH}$ values of the water were also read and recorded.

\subsubsection{Water Current or Flow Rate}

The water current (flow rate) was determined by timing a float [31]. Four eucalyptus plant leaves of almost equal weights were set on the water surface one after another and allowed to flow over a distance of $2 \mathrm{~m}$ and the time taken for each leaf to cover the distance recorded in seconds. The average time taken by 
the four leaves was then determined. This was repeated for each of the six sampling points. Then the water current or flow rate, $\mathrm{V}$ was then calculated from the expression, $\mathrm{V}=$ distance/time.

\subsubsection{Nitrite $\left(\mathrm{NO}_{2}^{-}\right)$}

Nitrite $\left(\mathrm{NO}_{2}^{-}\right)$concentrations were determined colorimetrically using Merck's rapid test kits [32]. The kit was opened and set up with both tubes on the left. The comparator block was slid all the way to the left so that the end holding the tubes protrudes laterally over the bottom part of the box. The color card was unfolded and inserted with the coloured end first into the slit at the lower right hand edge of the box. Water sample $(5 \mathrm{ml})$ was obtained from the sampling bottles using a syringe and then injected into test tube A (measurement sample) while the same volume of distilled water was injected into test tube B (blank). One microspoonful of $\mathrm{NO}_{2}-1$ reagent was obtained and added to test tube A with the sample and then it was closed, shaken vigorously until the reagent was completely dissolved. The test tube was left to stand for 3 minutes. The sample test tube with the reagent and the control test tube were placed into the slit. The colour card was slid through to the left until the closest possible colour match was achieved between the two open test tubes when viewed from above. $\mathrm{NO}_{2}^{-}$concentrations in $\mathrm{mg} / \mathrm{l}$ were read from the colour card at the lower right hand edge of the comparator block within the bottom part of the box.

\subsubsection{Phosphate $\left(\mathrm{PO}_{4}-\mathrm{P}\right)$}

Phosphate $\left(\mathrm{PO}_{4}-\mathrm{P}\right)$ concentrations were also determined colorimetrically using Merck's rapid test kits [33]. The kit was opened and set up with both tubes placed in the comparator slits behind the colour disk. Water sample $(6 \mathrm{ml})$ was obtained from the sampling bottles using a syringe and injected into test tube A (measurement sample) and same volume of distilled water was injected into test tube $\mathrm{B}$ (blank) while placed in the comparator slits behind the colour disk. Five drops of $\mathrm{PO}_{4}-1$ reagent was added into test tube $\mathrm{A}$ while kept in a vertical position and then it was closed, shaken vigorously until the reagent was completely dissolved. The test tube was left to stand for 1 minute in the slit of the comparator disk. The comparator was held to the light while kept upright and the disk rotated until the closest possible colour match was achieved between the two large windows of the comparator. $\mathrm{PO}_{4}-\mathrm{P}$ concentrations in $\mathrm{mg} / \mathrm{l}$ were read off in the small window of the comparator.

\subsection{Data Analysis}

The data were summarized in form of descriptive statistics (minimum, maximum, standard deviation, mean, standard error of the mean) and presented in tables and bar graphs. Comparisons of the physico-chemical parameters across the various landing sites and anthropogenic activities were carried out using one way ANOVA (F test) and Kruskal Wallis $(\mathrm{H})$ test while relationships between the parameters explored using spearman's correlation coefficient $\left(\mathrm{r}_{\mathrm{s}}\right)$. The above 
tests were done after verifications of the assumptions of normality of data and homogeneity of variance using Kolmogorov Smirnov (KS) and Levene (L) tests respectively. All the inferences were made at $5 \%$ level of significance with the analyses done using Microsoft Excel 2007 and SPSS 20 Computer packages.

\section{Results and Discussion}

\subsection{Physico-Chemical Parameters in Lake Kyoga}

The physico-chemical parameters across the various anthropogenic activities in the landing sites are presented in Table 1.

\subsubsection{Temperature}

Temperature as a physico-chemical parameter influences the overall quality of water through its effects on the physicochemical and biological characteristics of the water body including the rate of chemical reactions, solubility of gases e.g. oxygen etc. [34]. Temperature varied significantly $(p<0.05)$ across the various landing sites and human activities (Table 1) though with low variability within the samples, i.e. $\mathrm{CV}$ (landing sites $=1.87 \%-2.26 \%$; human activities $=1.70 \%$ $2.16 \%)$. Kayei had the highest temperature $\left(25.54^{\circ} \mathrm{C}\right)$ while Masindi port had the least $\left(25.12^{\circ} \mathrm{C}\right)$. On the other hand, waste sites recorded the highest temperature $\left(25.76^{\circ} \mathrm{C}\right)$ and gardens the least $\left(25.06^{\circ} \mathrm{C}\right)$. Temperature values also showed significant $(\mathrm{p}<0.05)$ variations at the anthropogenic activities in each of the landing sites with waste sites having the highest temperature in most of the landing sites except in Waitumba where temperature was highest at the fishing site (Figure 2). The slightly higher temperature at Kayei is due to the relatively lower water flow rate while the low temperature value at Masindi port is associated with mixing of water as a result of high flow rate. This is supported by the fact that flow rate was significantly negatively correlated with temperature $\left(\mathrm{r}_{\mathrm{s}}=-0.49, \mathrm{p}=\right.$ $0.02, \mathrm{n}=24)$ and Masindi port recorded significantly $(\mathrm{p}=0.05)$ the highest flow rate than other landing sites. With an average depth of only 3.6 meters, Lake Kyoga waters can easily be mixed. According to Beadle [35], Lake Kyoga is a polymictic lake which mixes on daily basis. Shallow water bodies have a high over turn which prevents them from undergoing thermal stratification from top to bottom. Due to the mixing, no heat storage occurs in any zone of the water body resulting into a general uniform low temperature of the shallow water body. The heat in the epilimnion zone is rather distributed uniformly to the lower cool layers of the water body hence a uniform low temperature in the entire water body [36]. The high temperature values in the waste sites may be attributed to the high decomposition of the wastes. According to Juma [37], decomposition of organic matter releases energy locked in bonds of the organic substances inform of heat thus raising the temperature at the waste sites more than other sites.

On the other hand, the low temperatures at the garden site may be due to increased mixing of the water near the garden despite the decomposition of organic matter from the garden. However, the temperature values in the study sites 
Table 1. Descriptive statistics of the physico-chemical parameters of Lake Kyoga across different landing sites and anthropogenic activities and comparison using one way ANOVA (F) and Kruskal Wallis (H) tests.

\begin{tabular}{|c|c|c|c|c|c|c|c|c|c|c|}
\hline Parameters & Location & Site/Activity & Min. & Max. & SD & CV (\%) & Mean \pm SE & $\mathrm{F}^{\mathrm{a}}$ or $\mathrm{H}^{\mathrm{b}}$ & $\mathrm{p}$ & $\begin{array}{c}\text { Standard } \\
{[39]}\end{array}$ \\
\hline \multirow{8}{*}{$\begin{array}{l}\text { Temperature } \\
\left({ }^{\circ} \mathrm{C}\right)(\mathrm{n}=72)\end{array}$} & \multirow{4}{*}{ Landing Site } & Kayei & 24.8 & 27.0 & 0.48 & 1.87 & $25.54 \pm 0.06$ & \multirow{4}{*}{$23.25^{b *}$} & \multirow{4}{*}{0.00} & \multirow{8}{*}{25} \\
\hline & & Acholi inn & 24.5 & 26.8 & 0.57 & 2.26 & $25.39 \pm 0.07$ & & & \\
\hline & & Waitumba & 24.5 & 26.5 & 0.53 & 2.11 & $25.36 \pm 0.06$ & & & \\
\hline & & Masindi port & 24.5 & 26.7 & 0.49 & 1.94 & $25.12 \pm 0.06$ & & & \\
\hline & \multirow{4}{*}{$\begin{array}{l}\text { Human } \\
\text { Activity }\end{array}$} & Boat dock & 24.5 & 26.3 & 0.45 & 1.77 & $25.30 \pm 0.05$ & \multirow{4}{*}{$63.19^{b *}$} & \multirow{4}{*}{0.00} & \\
\hline & & Waste site & 25.0 & 27.0 & 0.44 & 1.70 & $25.76 \pm 0.05$ & & & \\
\hline & & Garden & 24.5 & 26.5 & 0.47 & 1.90 & $25.06 \pm 0.06$ & & & \\
\hline & & Fishing & 24.5 & 26.5 & 0.55 & 2.16 & $25.30 \pm 0.06$ & & & \\
\hline \multirow{8}{*}{$\begin{array}{c}\mathrm{pH} \\
(\mathrm{n}=72)\end{array}$} & \multirow{5}{*}{ Landing Site } & Kayei & 5.7 & 7.5 & 0.34 & 4.98 & $6.88 \pm 0.04$ & \multirow{4}{*}{$21.80^{\mathrm{b} *}$} & \multirow{4}{*}{0.00} & \multirow{8}{*}{$5.5-8.5$} \\
\hline & & Acholi inn & 6.1 & 7.5 & 0.30 & 4.37 & $6.90 \pm 0.04$ & & & \\
\hline & & Waitumba & 6.2 & 7.5 & 0.29 & 4.26 & $6.90 \pm 0.03$ & & & \\
\hline & & Masindi port & 6.4 & 8.5 & 0.36 & 5.03 & $7.15 \pm 0.04$ & & & \\
\hline & & Boat dock & 6.6 & 8.0 & 0.26 & 3.77 & $7.01 \pm 0.03$ & & & \\
\hline & \multirow{3}{*}{$\begin{array}{l}\text { Human } \\
\text { Activity }\end{array}$} & Waste site & 5.7 & 8.5 & 0.52 & 7.78 & $6.73 \pm 0.06$ & \multirow{3}{*}{$58.95^{b *}$} & \multirow{3}{*}{0.00} & \\
\hline & & Garden & 6.4 & 7.5 & 0.17 & 2.44 & $6.99 \pm 0.02$ & & & \\
\hline & & Fishing & 6.8 & 7.5 & 0.14 & 2.00 & $7.11 \pm 0.02$ & & & \\
\hline \multirow{5}{*}{ Flow rate $(\mathrm{m} / \mathrm{s})$} & & Kayei & 0.00 & 0.02 & 0.009 & 54.39 & $0.016 \pm 0.004$ & \multirow{4}{*}{$3.07^{\mathrm{a} *}$} & \multirow{4}{*}{0.05} & \multirow{5}{*}{ - } \\
\hline & Landing Site & Acholi inn & $\begin{array}{c}0.01 \\
9\end{array}$ & $\begin{array}{c}0.03 \\
7\end{array}$ & 0.007 & 27.58 & $0.025 \pm 0.003$ & & & \\
\hline & $\begin{array}{c}(\mathrm{n}=6) \\
\left(\mathrm{F}_{3,20}\right)\end{array}$ & Waitumba & $\begin{array}{c}0.00 \\
0\end{array}$ & $\begin{array}{c}0.02 \\
7\end{array}$ & 0.011 & 82.66 & $0.013 \pm 0.004$ & & & \\
\hline & & Masindi port & $\begin{array}{c}0.01 \\
5\end{array}$ & $\begin{array}{c}0.06 \\
1\end{array}$ & 0.017 & 54.13 & $0.031 \pm 0.007$ & & & \\
\hline & $\begin{array}{l}\text { Human } \\
\text { Activity }\end{array}$ & Garden $(\mathrm{n}=24)$ & $\begin{array}{c}0.00 \\
0\end{array}$ & $\begin{array}{c}0.06 \\
1\end{array}$ & 0.013 & 60.841 & $0.021 \pm 0.003$ & - & - & \\
\hline \multirow{8}{*}{$\begin{array}{l}\mathrm{DO}(\mathrm{mg} / \mathrm{l}) \\
(\mathrm{n}=72)\end{array}$} & \multirow{5}{*}{ Landing Site } & Kayei & 1.3 & 15.0 & 2.61 & 21.33 & $12.23 \pm 0.31$ & \multirow{4}{*}{$4.48^{\mathrm{b}}$} & \multirow{4}{*}{0.21} & \multirow{8}{*}{$\geq 9$} \\
\hline & & Acholi inn & 5.0 & 14.6 & 2.11 & 17.67 & $11.94 \pm 0.25$ & & & \\
\hline & & Waitumba & 5.2 & 15.0 & 2.55 & 21.06 & $12.09 \pm 0.30$ & & & \\
\hline & & Masindi port & 5.3 & 14.8 & 1.89 & 15.71 & $12.06 \pm 0.22$ & & & \\
\hline & & Boat dock & 10.3 & 14.8 & 1.17 & 9.15 & $12.84 \pm 0.14$ & \multirow{4}{*}{$79.28^{\mathrm{b} *}$} & & \\
\hline & \multirow{3}{*}{$\begin{array}{l}\text { Human } \\
\text { Activity }\end{array}$} & Waste site & 5.0 & 14.1 & 2.94 & 28.96 & $10.15 \pm 0.35$ & & & \\
\hline & & Garden & 1.3 & 14.7 & 2.03 & 17.21 & $11.82 \pm 0.24$ & & 0.00 & \\
\hline & & Fishing & 11.3 & 15.0 & 0.86 & 6.36 & $13.50 \pm 0.10$ & & & \\
\hline & & Kayei & 0.1 & 0.8 & 0.22 & 78.35 & $0.28 \pm 0.05$ & & & \\
\hline Nitrite, & & Acholi inn & 0.0 & 0.8 & 0.26 & 83.88 & $0.31 \pm 0.05$ & & & \\
\hline$(\mathrm{n}=24)$ & Lalluing sile & Waitumba & 0.0 & 0.8 & 0.22 & 86.81 & $0.25 \pm 0.05$ & 0.45 & 0.70 & $\leq 0.03$ \\
\hline & & Masindi port & 0.0 & 0.8 & 0.25 & 90.85 & $0.28 \pm 0.05$ & & & \\
\hline
\end{tabular}




\section{Continued}

\begin{tabular}{|c|c|c|c|c|c|c|c|c|c|c|}
\hline & \multirow{4}{*}{$\begin{array}{l}\text { Human } \\
\text { Activity }\end{array}$} & Boat dock & 0.0 & 0.4 & 0.13 & 69.49 & $0.18 \pm 0.03$ & \multirow{4}{*}{$26.80^{\mathrm{b} *}$} & \multirow{4}{*}{0.00} & \\
\hline & & Waste site & 0.1 & 0.8 & 0.28 & 56.84 & $0.49 \pm 0.06$ & & & \\
\hline & & Garden & 0.0 & 0.7 & 0.22 & 69.99 & $0.32 \pm 0.05$ & & & \\
\hline & & Fishing & 0.0 & 0.3 & 0.09 & 68.76 & $0.13 \pm 0.02$ & & & \\
\hline \multirow{4}{*}{$\begin{array}{c}\text { Phosphate, } \\
\mathrm{PO}_{4} \cdot \mathrm{P}\left(\mathrm{P}_{2} \mathrm{O}_{5}\right) \\
\mathrm{mg} / \mathrm{l},(\mathrm{n}=24)\end{array}$} & \multirow{4}{*}{ Landing Site } & Kayei & $\begin{array}{c}0.0 \\
(0.0)\end{array}$ & $\begin{array}{c}0.7 \\
(1.6)\end{array}$ & $\begin{array}{l}0.21 \\
(0.48)\end{array}$ & 89.37 & $\begin{array}{c}0.24 \pm 0.04 \\
(0.55 \pm 0.09)\end{array}$ & \multirow{4}{*}{$3.99^{\mathrm{b}}$} & \multirow{4}{*}{0.26} & \multirow{8}{*}{$\begin{array}{c}0.5 \\
\left(\mathrm{P}_{2} \mathrm{O}_{5}\right)\end{array}$} \\
\hline & & Acholi inn & $\begin{array}{c}0.0 \\
(0.0)\end{array}$ & $\begin{array}{c}0.7 \\
(1.6)\end{array}$ & $\begin{array}{c}0.18 \\
(0.41)\end{array}$ & 75.33 & $\begin{array}{c}0.24 \pm 0.04 \\
(0.55 \pm 0.09)\end{array}$ & & & \\
\hline & & Waitumba & $\begin{array}{c}0.0 \\
(0.0)\end{array}$ & $\begin{array}{c}0.6 \\
(1.4)\end{array}$ & $\begin{array}{c}0.16 \\
(0.37)\end{array}$ & 79.40 & $\begin{array}{c}0.20 \pm 0.03 \\
(0.46 \pm 0.07)\end{array}$ & & & \\
\hline & & Masindi port & $\begin{array}{c}0.0 \\
(0.0)\end{array}$ & $\begin{array}{c}0.5 \\
(1.1)\end{array}$ & $\begin{array}{c}0.12 \\
(0.27)\end{array}$ & 76.59 & $\begin{array}{c}0.16 \pm 0.03 \\
(0.37 \pm 0.07)\end{array}$ & & & \\
\hline \multirow{4}{*}{$\begin{array}{c}1 \mathrm{mg} / \mathrm{l} \mathrm{PO} \cdot \mathrm{P}_{4} \mathrm{P}= \\
2.29 \mathrm{mg} / \mathrm{P}_{2} \mathrm{O}_{5} \\
{[33]}\end{array}$} & \multirow{4}{*}{$\begin{array}{l}\text { Human } \\
\text { Activity }\end{array}$} & Boat dock & $\begin{array}{c}0.0 \\
(0.0)\end{array}$ & $\begin{array}{c}0.3 \\
(0.7)\end{array}$ & $\begin{array}{c}0.09 \\
(0.21)\end{array}$ & 68.76 & $\begin{array}{c}0.13 \pm 0.02 \\
(0.30 \pm 0.05)\end{array}$ & \multirow{4}{*}{$24.22^{\mathrm{b} *}$} & \multirow{4}{*}{0.00} & \\
\hline & & Waste site & $\begin{array}{c}0.1 \\
(0.2)\end{array}$ & $\begin{array}{c}0.7 \\
(1.6)\end{array}$ & $\begin{array}{c}0.20 \\
(0.46)\end{array}$ & 59.06 & $\begin{array}{c}0.35 \pm 0.04 \\
(0.80 \pm 0.09)\end{array}$ & & & \\
\hline & & Garden & $\begin{array}{c}0.0 \\
(0.0)\end{array}$ & $\begin{array}{c}0.7 \\
(1.6)\end{array}$ & $\begin{array}{c}0.17 \\
(0.39)\end{array}$ & 70.01 & $\begin{array}{c}0.24 \pm 0.03 \\
(0.55 \pm 0.07)\end{array}$ & & & \\
\hline & & Fishing & $\begin{array}{c}0.0 \\
(0.0)\end{array}$ & $\begin{array}{c}0.3 \\
(0.7)\end{array}$ & $\begin{array}{c}0.09 \\
(0.21)\end{array}$ & 74.41 & $\begin{array}{c}0.12 \pm 0.02 \\
(0.27 \pm 0.05)\end{array}$ & & & \\
\hline
\end{tabular}

*Significant ( $\mathrm{p} \leq$ 0.05); Min.-minimum; Max.-maximum; SD-standard deviation; SE-Standard error of the mean; CV.-coefficient of variation; $\mathrm{F}$-data normally distributed and same variances; $\mathrm{H}$-data not normally distributed and variances are different; Kolmogorov-Smirnov $\mathrm{p}>0.05$, normally distributed; Lp-Levene $\mathrm{p}>0.05$, same variances.

\section{Landing Site}

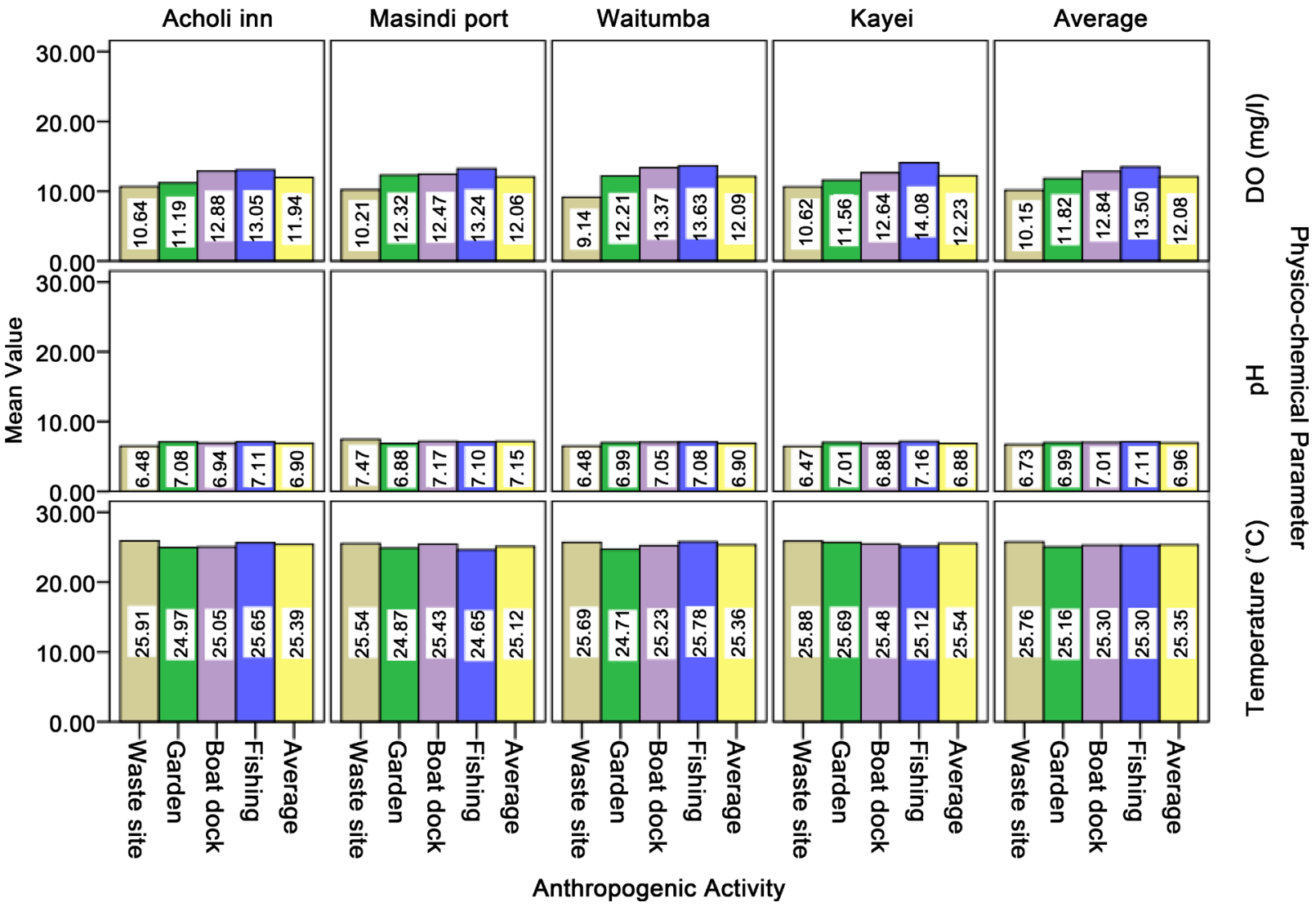

Figure 2. Physico-chemical parameters (temperature, $\mathrm{pH}, \mathrm{DO}$ ) at the various anthropogenic activities in the landing sites. 
with an overall average of $25.35^{\circ} \mathrm{C}$ (Figure 2) were slightly lower than the range of water temperatures of Lake Kyoga $\left(26^{\circ} \mathrm{C}-30^{\circ} \mathrm{C}\right)$ reported by Hughes and Hughes [38] and those for some small lakes $\left(26^{\circ} \mathrm{C}-28^{\circ} \mathrm{C}\right)$ in the basin [14]. However the recorded temperatures at the study sites were slightly higher than the standard of $25^{\circ} \mathrm{C}$ [39] evidencing warmer waters. According to Mungoma [26], Lake Kyoga can be categorized as warm polymictic. Furthermore, sampling was done during the months of December and January with low rainfall and high maximum temperatures [28] [40].

\subsection{2. $\mathrm{pH}$}

$\mathrm{pH}$ is the negative logarithm of the hydrogen ion concentration of a solution and is a measure of whether the liquid is acidic or alkaline. It ranges from 1 (very acidic) to 14 (very alkaline) [39]. The $\mathrm{pH}$ of a water body is a useful parameter as most biological activities of organisms occur within a narrow $\mathrm{pH}$ range. There are fatal consequences posed to a particular organism in case $\mathrm{pH}$ varies beyond the required limit [41]. $\mathrm{pH}$ values also govern several other important parameters of water quality, e.g. ammonia toxicity, chlorine disinfection efficiency, and metal solubility [39]. There was a significant $(\mathrm{p}<0.05)$ variation of $\mathrm{pH}$ across the various landing sites and human activities (Table 1 ) with also low variability within samples $(\mathrm{CV}$; landing sites $=4.26-5.03 \%$; human activities $=2.0 \%$ $7.78 \%)$. Masindi port registered the highest $\mathrm{pH}$ (7.15) while Kayei had the lowest (6.88). On the other hand, fishing areas recorded the highest $\mathrm{pH}$ (7.11) and waste sites the least $(6.73)$. pH also significantly varied $(\mathrm{p}<0.05)$ at the anthropogenic activities in each of the landing sites with fishing sites having the highest $\mathrm{pH}$ in most of the landing sites except in Masindi port where $\mathrm{pH}$ was highest at the waste site (Figure 2). The waste sites recorded the least $\mathrm{pH}$ in the rest of the landing sites.

The least $\mathrm{pH}$ at the waste sites followed by garden is associated with the production of organic acids during the decomposition of organic wastes [42]. As the amount of available dissolved oxygen required for the decomposition of organic constituents (carbohydrates, proteins and lipids) of the organic matter in the waste sites and gardens decreases, the organic compounds undergo anaerobic fermentation processes leading to ammonia and organic acids [43]. For instance, decomposition of organic matter forms humus which produces a lot of humic acids especially in agricultural areas [37] [42]. Hydrolysis of these acidic materials causes a decrease of water $\mathrm{pH}$ values [43]. The high $\mathrm{pH}$ at Masindi port may be attributed to the mixing of the water due to the slightly high water flow rate despite the formation of the acidic compounds from the decomposition of organic matter from the waste sites. The overall temperature was significantly negatively correlated with $\mathrm{pH}\left(\mathrm{r}_{\mathrm{s}}=-0.23, \mathrm{p}=0.00, \mathrm{n}=288\right)$ since decomposition of organic wastes also generates some heat [37].

Fishing areas are relatively deeper portions of the lake with less organic matter hence low decomposition compared to the shallower shoreline areas used as boat dock with a lot of organic matter hence increased decomposition thus justifying 
the high $\mathrm{pH}$ in the fishing areas and the relatively low $\mathrm{pH}$ at the boat docks. However, the $\mathrm{pH}$ values in the study sites $(6.73-7.15)$ with an overall average of 6.96 (Figure 2) were below the $\mathrm{pH}$ range (7.6 - 9.0) of Lake Kyoga obtained by Hughes and Hughes [38]. However, the obtained $\mathrm{pH}$ values of the lake were within the $\mathrm{pH}$ range of $5.5-8.5$ [39]. The obtained $\mathrm{pH}$ values of Lake Kyoga are also circumneutral to slightly alkaline similar to the $\mathrm{pH}$ of most small lakes in Lake Kyoga basin. This can also be attributed to the high buffering capacity of Lake Kyoga as previously reported by NaFIRRI [14] for the small lakes in the ba$\sin$.

\subsubsection{Flow Rate}

Measuring the flow rate of water is the first step to good water management [31]. Flow rate significantly $(\mathrm{p}<0.05)$ varied across the various landing sites (Table 1) with high variability within the samples ( $\mathrm{CV}=27.58 \%-82.66 \%)$. Masindi port recorded the highest flow rate $(0.031 \mathrm{~m} / \mathrm{s})$ while Waitumba had the least $(0.013 \mathrm{~m} / \mathrm{s})$. The overall flow rate with the measurements taken near gardens is $0.021 \mathrm{~m} / \mathrm{s}$.

The difference in the rate of water flow at the selected landing sites is due to their relative proximity to river Kafu that pours its waters into the lake and causes a drag of water increasing its flow. According to NEMA [10], river Kafu which straddles the border of Nakasongola and Masindi channels into Lake Kyoga. Masindi port being the closest to the river has the highest flow rate. Gibb [44] earlier on reported that the water balance of Lake Kyoga and its catchment area including the Kafu has a seasonal effect on the flows at Masindi Port just below the outlet from the lake. Slightly opposite Masindi port is Waitumba landing site but with the least flow rate. This anomaly of flow rate at Waitumba landing site would be attributed to the relative curve created by papyrus and water hyacinth (Eichornia crassipes) around this site which is also located close to the shoreline. The papyrus and water hyacinth (Eichornia crassipes) tend to absorb the dragging effect of water reducing on the water velocity. According to Twongo et al. [45], the shore environments of Lake Kyoga with potential for the establishment and proliferation of water hyacinth are sheltered from violent off-shore and along-the-shore wind and wave action. However, the obtained average flow rate $(0.021 \mathrm{~m} / \mathrm{s})$ is relatively low probably attributed to low rainfall, i.e. dry periods during the sampling months (December, January). According to Vega et al. [43], flow rate decreases in the dry seasons. Generally, the buffering capacity of the lake from acidic conditions increased with flow rate thus the significant positive correlation between flow rate and $\mathrm{pH}\left(\mathrm{r}_{\mathrm{s}}=0.45, \mathrm{p}=0.03, \mathrm{n}=24\right)$. They further stated that flow rate causes dilution of contaminants.

\subsubsection{Dissolved Oxygen (DO)}

Dissolved oxygen (DO) is a useful water quality parameter and an index of physical and biological processes in water which favor solubility of oxygen [46]. Organic matter discharged into oxygen saturated waters as food source is broken 
down into less complex organic substances by aerobic bacteria. However, the rate of bacterial uptake of oxygen outstrips DO replenishment from the atmosphere and photosynthesis in case of large quantity of wastes, hence creating anaerobic conditions in the water [39]. As shown in Table 1, there was relatively high variability of DO within the samples across the various landing sites and human activities, i.e. CV (landing sites $=15.71 \%-21.33 \%$; human activities = $6.36 \%-28.96 \%)$. Kayei recorded the highest DO $(12.23 \mathrm{mg} / \mathrm{l})$ and Acholi inn, the lowest $(11.94 \mathrm{mg} / \mathrm{l})$ but the differences in DO values within the landing sites were insignificant $(\mathrm{p}>0.05)$ (Table 1$)$. The overall mean of DO at the study sites was $12.08 \mathrm{mg} / \mathrm{l}$ (Figure 2). According to a report by NaFIRRI [14], most Kyoga basin lakes are well aerated with minimum DO concentration always above $5 \mathrm{mg}$ $\mathrm{L}^{-1}$. Hence all the studied landing sites with mean DO above $5 \mathrm{mg} / \mathrm{l}$ and insignificant DO variations are equally aerated. Furthermore, the obtained DO concentrations at all the study sites of the lake were within the standard value of $\geq 9.0$ [39]. Mungoma [26], earlier on reported that Lake Kyoga is saturated with DO most of the time with measurements ranging between $87 \%-126 \%$ DO saturation.

On the other hand, DO varied significantly $(\mathrm{p}<0.05)$ across the various human activities. Fishing areas had the highest DO $(13.5 \mathrm{mg} / \mathrm{l})$ and the waste sites the least $(10.15 \mathrm{mg} / \mathrm{l})$. DO values significant $(\mathrm{p}<0.05)$ varied across anthropogenic activities in most of the landing sites except in Acholi inn where there was no significant difference ( $p>0.05)$. However in all the landing sites, the fishing areas had the highest DO followed by boat dock, garden and lastly the waste sites (Figure 2). The low DO in the waste sites is associated with increased decomposition of organic matter which requires oxygen especially during aerobic decomposition. According to Kristensen et al. [47], oxygen plays two important functions during the degradation of organic matter, i.e. is a terminal electron acceptor for electrons released during oxidation of organic carbon and is a reactant in the oxygenase catalyzed primary attack on the substrate molecules. Thus high levels of organic matter consume large amounts of oxygen [43].

The high DO in the fishing areas may be attributed to either low decomposition of little organic matter in the fishing areas or low coverage of the water surface by any vegetation mat which hinders the dissolution of oxygen. Fishermen also usually clear any surface vegetation covering to create way for fishing. The least recorded minimum DO was at the garden site in Kayei $(1.3 \mathrm{mg} / \mathrm{l})$ also attributable to decomposition of organic matter from the garden. The least minimum DO was below the minimum DO $(3.8 \mathrm{mg} / \mathrm{l})$ recorded in some of the small lakes in Kyoga basin [38].

The decomposition of organic matter by aerobic bacteria (which uses oxygen) forms humic acid thus lowering $\mathrm{pH}$. This justifies the significant positive correlation between $\mathrm{pH}$ and $\mathrm{DO}\left(\mathrm{r}_{\mathrm{s}}=0.38, \mathrm{p}=0.00, \mathrm{n}=96\right)$. The significant positive correlation between $\mathrm{pH}$ and $\mathrm{DO}$ could also be attributed to increased photosynthesis in the lake. According to Lukubye and Andama [48], high photosynthetic 
rates in low-velocity waters which reduce the available carbon dioxide (increasing the $\mathrm{pH}$ ) would liberate oxygen leading to positive correlation between DO and $\mathrm{pH}$. On overall, there was also a significant positive correlation between $\mathrm{DO}$ and flow rate $\left(r_{s}=0.69, p=0.00, n=24\right)$ signifying that high water flow rate enhances mixing of the water hence increased oxygen circulation in the lake. Vega et al. [43], obtained higher flow rate and dissolved oxygen, an indication of a better water quality. As expected, temperature was significantly negatively correlated with dissolved oxygen $\left(r_{s}=0.36, p=0.00, n=288\right)$ since solubility of oxygen in water decreases with increase in temperature [43] [49] [50].

\subsubsection{Nitrites $\left(\mathrm{NO}_{2}^{-}\right)$}

Nitrite $\left(\mathrm{NO}_{2}^{-}\right)$is one of the forms of nitrogen which usually occurs in minute concentrations with even relatively low levels in the waste treatment plant effluents since nitrogen tends to exist in the more reduced (ammonia; $\mathrm{NH}_{3}$ ) or more oxidised (nitrate; $\mathrm{NO}_{3}$ ) forms. Unpolluted waters have low nitrite $(<0.03 \mathrm{mg} / \mathrm{l})$ and values above $0.03 \mathrm{mg} / \mathrm{l}$ may indicate sewage pollution [39]. Hence the significance of nitrite is mainly as an indicator of any likely sewage pollution. Nitrite is also a direct toxicant with some carcinogenic effects thus stricter nitrite limit in drinking waters [39].

Table 1 shows that there was high variability of $\mathrm{NO}_{2}^{-}$within the samples across the various landing sites and human activities (CV, landing sites $=78.35 \%$ - 90.85\%; human activities $=56.84 \%-69.99 \%)$. Nitrites did not vary significantly ( $\mathrm{p}>0.05)$ in the different landing sites though Acholi inn recorded the highest $\mathrm{NO}_{2}^{-}(0.31 \mathrm{mg} / \mathrm{l})$ while Waitumba the lowest value $(0.25 \mathrm{mg} / \mathrm{l})$. On the other hand, $\mathrm{NO}_{2}^{-}$concentrations were significantly $(\mathrm{p}<0.05)$ different in the various human activities. Waste sites had the highest $\mathrm{NO}_{2}^{-}(0.49 \mathrm{mg} / \mathrm{l})$ and the fishing areas the least $(0.13 \mathrm{mg} / \mathrm{l})$. Nitrites significantly $(\mathrm{p}<0.05)$ varied across the anthropogenic activities in most of the landing sites except in Kayei where there was no significant difference $(\mathrm{p}>0.05)$. Nitrites were highest in the waste sites followed by garden, boat dock and least in the fishing areas in most of the landing sites (Figure 3).

The high $\mathrm{NO}_{2}^{-}$in the waste sites followed by garden and boat dock is due to the decomposition of organic matter (animal wastes and plant remains) from the waste sites and gardens. At low oxygen concentrations, the organic compounds (carbohydrates, proteins and lipids) in the organic matter from the waste sites and gardens usually undergo anaerobic fermentation processes forming ammonia [43]. Since nitrite is an intermediate product in the oxidisation of ammonia to nitrate [39], the higher the amount of ammonia, the more the nitrite concentrations hence the high $\mathrm{NO}_{2}^{-}$levels in the waste sites followed by gardens respectively. Since the oxidation of ammonia in the animal and human wastes as well as from decomposition of plant remains requires oxygen, the significant negative correlation of DO with $\mathrm{NO}_{2}^{-}\left(\mathrm{r}_{\mathrm{s}}=-0.72, \mathrm{p}=0.00, \mathrm{n}=96\right)$ is likely. Vega et al. [43] stated that nitrogen compounds are anti-correlated with dissolved oxygen as organic matter is partially oxidized by oxygen. 


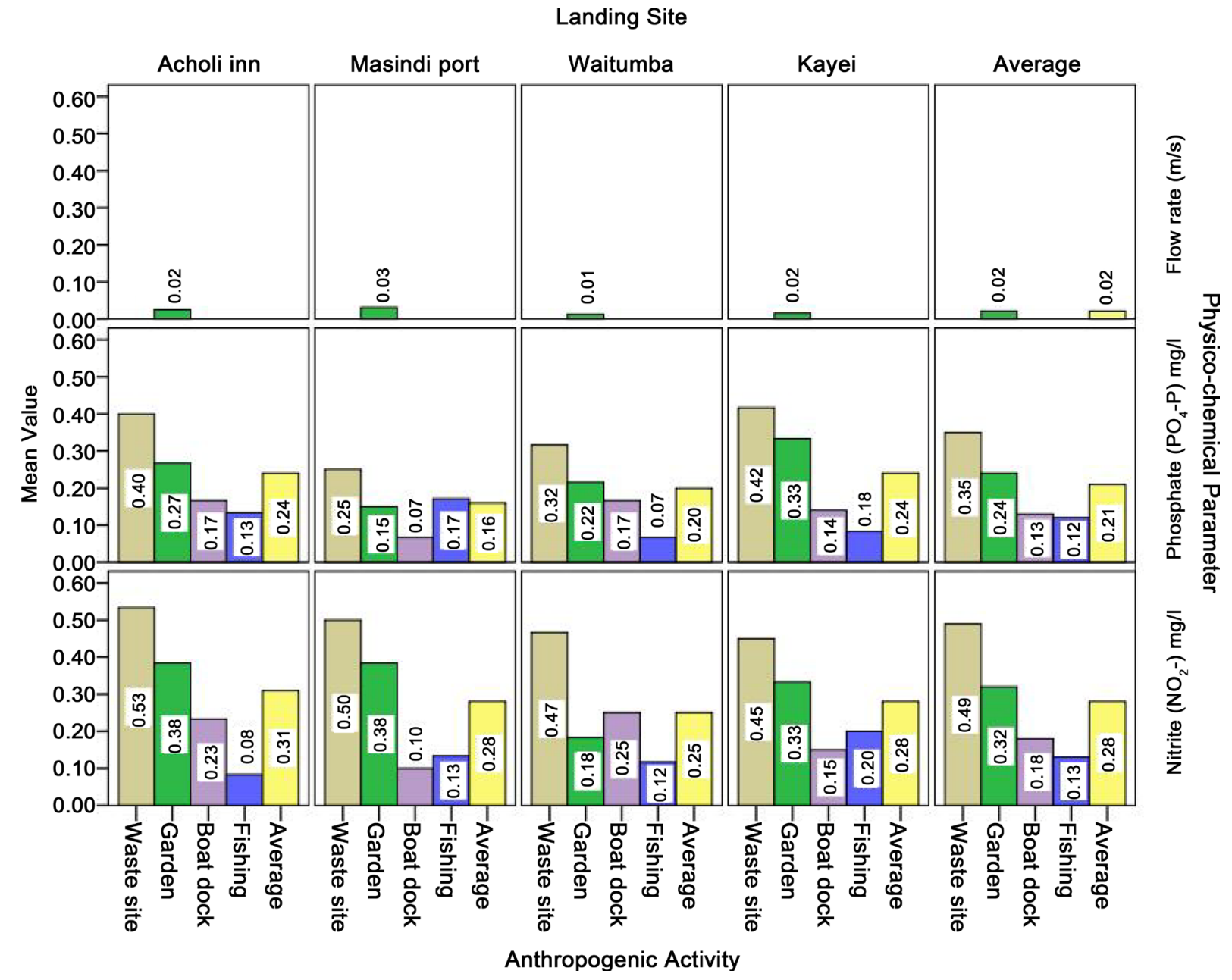

Figure 3. Physico-chemical parameters (nitrite, phosphate, flow rate) at the various anthropogenic activities in the landing sites.

The generated $\mathrm{H}^{+}$from the oxidation of ammonia or from the production of organic acids during the decomposition of organic matter (e.g. humic acids) creates some acid conditions thus the significant negative correlation of $\mathrm{pH}$ with $\mathrm{NO}_{2}^{-}$ $\left(\mathrm{r}_{\mathrm{s}}=-0.43, \mathrm{p}=0.00, \mathrm{n}=96\right)$. Furthermore, as the decomposition of organic matter (forming $\mathrm{NO}_{2}^{-}$as one of the intermediate products) generates heat, there is increase in temperature hence the significant positive correlation of temperature with $\mathrm{NO}_{2}^{-} \quad\left(\mathrm{r}_{\mathrm{s}}=0.40, \mathrm{p}=0.00, \mathrm{n}=96\right)$. Fishing areas with the least $\mathrm{NO}_{2}^{-}$levels are relatively deeper portions of the lake which receive less animal and human wastes hence low $\mathrm{NO}_{2}^{-}$. There was also a significant negative correlation between flow rate and $\mathrm{NO}_{2}^{-}\left(\mathrm{r}_{\mathrm{s}}=-0.52, \mathrm{p}=0.01, \mathrm{n}=24\right)$. According to Vega et al. [43], flow rate dilutes pollutants of anthropogenic origin hence the negative correlation with nitrites.

The insignificant variation of $\mathrm{NO}_{2}^{-}$levels in the different landing sites on Lake Kyoga may be attributed to uniform disposal of sewage (animal and human wastes) and agricultural wastes in the landing sites from the increased numbers of animals and people in the catchment. Furthermore $\mathrm{NO}_{2}^{-}$levels in all the study sites were above the standard value of $0.03 \mathrm{mg} / \mathrm{l}$ [39] confirming the in- 
creased sewage pollution in the study sites. Moreover the wastes including sewage disposed in Kyoga catchment are untreated. This is confirmed by a recommendation by the people within Lake Kyoga basin to purify wastes around the lake [8]. According to Cohen et al. [4], pollution problems are compounded for the African Great Lakes including Lake Kyoga by pollutant disposal. Most urban areas around the lakes have either very limited or no sewage treatment capacity hence raw sewage is discharged directly into the lakes [51].

\subsubsection{Phosphates $\left(\mathrm{PO}_{4}-\mathrm{P}\right)$}

The importance of phosphorus is mainly in regard to the phenomenon of eutrophication of lakes. Phosphorus and nitrogen promote the growth of algae leading to blooms. Orthophosphate $\left(\mathrm{PO}_{4}-\mathrm{P}\right)$ is the most readily used form of phosphates for the growth of algae [39] including other phytoplanktons. Hence the determination of orthophosphate highlights the presence of one of the most important nutrients especially in waters receiving sewage discharges [39]. Phosphates $\left(\mathrm{PO}_{4}-\mathrm{P}\right)$ also exhibited high variability within the samples across the various landing sites (Table 1 ) and human activities (CV, landing sites $=75.33 \%-89.37 \%$; human activities $=59.0 \%-74.41 \%)$. There was also no significant difference $(\mathrm{p}>$ $0.05)$ in the mean values of $\mathrm{PO}_{4}-\mathrm{P}$ across the different landing sites much as Acholi inn and Kayei recorded the highest $\mathrm{PO}_{4}-\mathrm{P}$ concentrations $(0.24 \mathrm{mg} / \mathrm{l})$ while Masindi port had the least value $(0.16 \mathrm{mg} / \mathrm{l})$. However, $\mathrm{PO}_{4}-\mathrm{P}$ concentrations showed significant $(\mathrm{p}<0.05)$ variation in the various human activities. Similarly $\mathrm{PO}_{4}-\mathrm{P}$ was highest at the waste sites $(0.35 \mathrm{mg} / \mathrm{l})$ and lowest in the fishing areas $(0.12 \mathrm{mg} / \mathrm{l}) . \mathrm{PO}_{4}-\mathrm{P}$ only differed significantly $(\mathrm{p}<0.05)$ in the various anthropogenic activities in Kayei landing site whereas there was no significant difference in the rest of the landing sites. The highest $\mathrm{PO}_{4}-\mathrm{P}$ levels were also recorded in the waste sites followed by garden, boat dock and the least in the fishing areas in the majority of the landing sites (Figure 3).

The high $\mathrm{PO}_{4}-\mathrm{P}$ in the waste sites followed by garden and boat dock is due to the potential source of $\mathrm{PO}_{4}-\mathrm{P}$ from the wastes and plant remains from the gardens. According to Lavelle and Spain [52], organic matter decomposition is a good source of nitrogen and phosphorus. NEMA [10] reported an increase in wastes into Lake Kyoga (and associated plant nutrients-nitrogen and phosphorous) hence enriched nutrients (e.g. phosphates) into the lake. Additionally, Breeuwsma [53] reported that animal wastes and plant remains enrich the waters with phosphates. Furthermore, boat docks are located in the shallower shoreline areas which receive a lot of organic matter from the land surface and the bottom of the lake is constantly disturbed by the docking of the boat and this easily circulates the phosphates to the upper surface. Twongo et al. [45] found out that the shore environment of Lake Kyoga is characterised by a muddy bottom rich in organic matter with relatively shallower water. On the other hand, $\mathrm{PO}_{4}-\mathrm{P}$ concentrations were also low in the fishing areas attributable to the fact that fishing areas are relatively deeper portions of the lake which receive less plant remains and organic matter and their bottom sediments (potential source of nutrients, 
i.e. $\mathrm{P}$ ) are less disturbed hence low $\mathrm{PO}_{4}-\mathrm{P}$ concentrations in their upper photosynthetic zones. Hecky and Bugenyi [12] found higher phosphorus $\left(\mathrm{PO}_{4}-\mathrm{P}\right)$ concentrations near the mud surface and lower in the upper photosynthetic zone of Lake Kyoga. However the relatively low overall phosphates $\left(\mathrm{PO}_{4}-\mathrm{P}\right)$ in the study sites may be associated with less transportation of the phosphates into the lake due to low rainfall since sampling was done in December and January i.e., months with low rainfall [28].

Aerobic decomposition of the organic matter (with the production of humic acid) to release phosphates also utilizes oxygen thus a significant negative correlation of DO with $\mathrm{PO}_{4}-\mathrm{P}\left(\mathrm{r}_{\mathrm{s}}=-0.66, \mathrm{p}=0.00, \mathrm{n}=96\right)$. Furthermore, Vega et al. [43] also reported that phosphorous compounds are negatively correlated with dissolved oxygen as organic matter is partially oxidized by oxygen. Similarly, $\mathrm{pH}$ was significantly negatively correlated with $\mathrm{PO}_{4}-\mathrm{P}\left(\mathrm{r}_{\mathrm{s}}=-0.45, \mathrm{p}=0.00, \mathrm{n}=96\right)$. On the other hand, as the decomposition process (forming $\mathrm{PO}_{4}-\mathrm{P}$ ) generates heat, it increases the temperature hence the significant positive correlation of temperature with $\mathrm{PO}_{4}-\mathrm{P}\left(r_{s}=0.40, \mathrm{p}=0.00, \mathrm{n}=96\right)$. Since the nitrites and phosphates are produced by the same material i.e. mainly decomposition of organic matter, there is a significant positive correlation between $\mathrm{NO}_{2}^{-}$and $\mathrm{PO}_{4}-\mathrm{P}\left(\mathrm{r}_{\mathrm{s}}=\right.$ $0.67, \mathrm{p}=0.01, \mathrm{n}=96)$. Similarly, the significant negative correlation of flow rate with $\mathrm{PO}_{4}-\mathrm{P}\left(\mathrm{r}_{\mathrm{s}}=-0.74, \mathrm{p}=0.00, \mathrm{n}=24\right)$ is expected since increase in flow rate causes dilution of contaminants of anthropogenic origin [43].

The insignificant variation of $\mathrm{PO}_{4}-\mathrm{P}$ concentrations in the different landing sites on Lake Kyoga concurs with the report by NaFIRRI [14] which showed that phosphates $\left(\mathrm{PO}_{4}-\mathrm{P}\right)$ were relatively evenly distributed in Lake Kyoga. Whereas the even distribution of phosphates $\left(\mathrm{PO}_{4}-\mathrm{P}\right)$ reported by NaFIRRI [14] was attributed to natural phenomena, the insignificant variation in this study may be due to comparatively equal contribution of $\mathrm{PO}_{4}-\mathrm{P}$ by the investigated anthropogenic activities in the selected landing sites. The levels of phosphates $\left(\mathrm{PO}_{4}-\mathrm{P}\right)$ when converted to $\mathrm{P}_{2} \mathrm{O}_{5}$ exceeds the standard value of $0.5 \mathrm{mg} / 1$ [39] especially in Kayei and Acholi landing sites as well as at the waste sites and gardens possibly due to increased human activities in the catchment at those sites. According to NaFIRRI [14], the present elevated levels of phosphates in Lake Kyoga are mainly caused by human activities in the catchment.

\section{Conclusions}

The high concentrations of nitrites in Lake Kyoga at the investigated anthropogenic activities and landing sites plus phosphate amounts close to waste sites and gardens including Kayei and Acholi inn landing sites call for vigilance in protection of Lake Kyoga through optimized planning.

Hence, National Environment Management Authority should ensure proper sewage management in Lake Kyoga catchment to avoid discharge of untreated sewage into the lake. The authority should also regulate waste dumping and cultivation around the lake so as to reduce nutrient (phosphorus) enrichment. 


\section{Acknowledgements}

The authors wish to acknowledge the technical support of National Water and Sewerage Corporation, Masindi especially during sampling and analysis of the water parameters. The authors also extend appreciation to the Department of Biology, Mbarara University of Science and Technology for the guidance and support during the entire research period and preparation of this paper.

\section{References}

[1] Ogutu-Ohwayo, R., Hecky, R.E., Cohen, A.S. and Kaufman, L. (1997) Human Impacts on the African Great Lakes. Environmental Biology of Fishes, 50, 117-131. https://doi.org/10.1023/A:1007320932349

[2] Japan International Cooperation Agency (JICA) (2011) The Development Study on Water Resources Development and Management for Lake Kyoga Basin in the Republic of Uganda. Final Report Summary. Ministry of Water and Environment. http://open_jicareport.jica.go.jp/pdf/12025201_01.pdf

[3] Kaggwa, R., Hogan, R. and Gowa, E. (2004) Policy Brief: Land Use Change, Land Degradation and Human Welfare: Lessons Learned from the Lake Kyoga catchment Area. UNDP-UNEP Poverty-Environment Initiative, Nairobi, Kenya.

[4] Cohen, A.S., Kaufman, L. and Ogutu-Ohwayo, R. (1996) Anthropogenic Threats, Impacts and Conservation Strategies in the African Great Lakes-A Review. In: Johnson, T.C. and Odada, E., Eds., The Limnology, Climatology and Paleoclimatology of the East African Lakes, Gordon \& Breach Scientific Publishers, Toronto, Canada.

[5] Ministry of Water and Environment, Wetland Management Department (2010) State of Wetlands Report. Ministry of water and Environment, Kampala.

[6] Gyllenhammar, A. (2017) Using Modeling, Gis and Remote Sensing to Understand an African Lake. http://wldb.ilec.or.jp/ILBMTrainingMaterials/resources/Kyoga.pdf

[7] State of the River Nile Basin (2012) The Role of Inland Water Transport in Support of Further Regional Integration.

http://nileis.nilebasin.org/system/files/Nile\%20SoB\%20Report\%20Chapter\%207\%2 0-\%20Transport.pdf

[8] Fisheries Training Institute (2004) Selected Fish Landing Sites and Fishing Communities. Survey Undertaken by Fisheries Training Institute for the DFID Project: Impacts of Globalisation on Fish Utilisation and Marketing Systems in Uganda. https://assets.publishing.service.gov.uk/media/57a08cd8e5274a31e00014b2/R8112k. pdf

[9] National Environment Management Authority (NEMA) (2001) National State of the Environment Report for Uganda, 2000/2001. National Enviornment Management Authority (NEMA), Kampala.

[10] National Environment Management Authority (NEMA) (2008) Pilot Integrated Environment Assessment of the Lake Kyoga Catchment Area. National Environment Management Authority (NEMA), Kampala.

[11] Coulter, G.W. and Jackson, P.N.B. (1981) Deep Lakes. In: Symoens, J., Burgis, M. and Gaudet, J., Eds., The Ecology and Utilization of African Inland Waters, UNEP Reports and Proceedings Series 1, 114-124.

[12] Hecky, R.E. and Bugenyi, F.W.B. (1992) Hydrology and Chemistry of the Great Lakes and Water Quality Issues: Problems and Solutions. Mitteilungen Internationale Vereinigung für Limnologie, 23, 45-54. 
[13] Bootsma, H. and Hecky, R.E. (1993) Conservation of the African Great Lakes: A Limnological Perspective. Conservation Biology, 7, 644-656. https://doi.org/10.1046/j.1523-1739.1993.07030644.x

[14] National Fisheries Resources Research Institute, NaFIRRI (2007) A Study on Stock Enhancement/Restocking of the Kyoga Basin Lakes. A Review of Kyoga Basin Lakes. National Fisheries Resources Research Institute (NaFIRRI), Jinja.

[15] Magezi, G., Mugidde, R. and Naluwairo, J. (2000) Physico-Chemical Characteristics and Algal Production of the Kyoga Basin Lakes and Rivers. In: Proceedings of a Stakeholder Workshop on Kyoga Basin lakes, Management of the Fish Stocks, Biodiversity and the Environment of Kyoga, National Fisheries Resources Research Institute, Jinja.

[16] Ndawula, L., Twongo, T. and Magezi, G. (2001) The Role of Lake Productivity Process in Fishery Production. In: Proceedings of a Training Workshop towards Empowering Fisheries Officers to Manage the Fish Stocks, Biodiversity and Environment of Kyoga Basin Lakes, National Fisheries Resources Research, Jinja.

[17] Twongo, T. (2002) The Fisheries and Environment of Kyoga Lakes. A Review Prepared for the Cooperative for Relief Everywhere (CARE).

[18] Evans, J.H. (1962a) The Distribution of Phytoplankton in Some Central East African Waters. Hydrobiologia, 19, 299-315. https://doi.org/10.1007/BF00042989

[19] Evans, J.H. (1962b) Some New Records and Forms of Algae in Central East Africa. Hydrobiologia, 20, 59-85. https://doi.org/10.1007/BF00038736

[20] Talling, J.F. and Talling, I.B. (1965) The Chemical Composition of African Lake Waters. International Review of Hydrobiology, 51, 545-621. https://doi.org/10.1002/iroh.19660510402

[21] Visser, S.A. (1974) Composition of Waters of Lakes and Rivers in East and West Africa. African Journal of Tropical Hydrobiology and Fisheries, 3, 43-60.

[22] Beadle, L.C. (1974) The Inland Waters of Tropical Africa. An Introduction to Tropical Limnology. Longman, London.

[23] Brown, E. and Sutcliffe, J.V. (2013) The Water Balance of Lake Kyoga, Uganda. Hydrological Sciences Journal, 58, 342-353.

https://doi.org/10.1080/02626667.2012.753148

[24] Burgis, M. and Symoens, J.J. (1987) Lake Kyoga and Associated Lakes. In: African Wetlands and Shallow Water Bodies.

[25] Twongo, T. (1991) The Fisheries of the Kyoga Lakes and the Likely Impact on Them by Human Activities in the Catchment. Uganda Freshwater Fisheries Research Organization, Jinja.

[26] Mungoma, S. (1988) Horizontal Differentiation in the Limnology of a Tropical River-Lake (Lake Kyoga, Uganda). Hydrobiologia, 162, 89-96. https://doi.org/10.1007/BF00014336

[27] Oxford University Press (2010) A Dictionary of Science. 6th Edition, Oxford University Press, Oxford.

[28] Nsubuga, F.W.N., Botai, O.J., Olwoch, J.M., Rautenbach, C.J., Bevis, Y. and Adetunji, A.O. (2014) The Nature of Rainfall in the Main Drainage Sub-Basins of Uganda. Hydrological Sciences Journal, 59, 278-299. https://doi.org/10.1080/02626667.2013.804188

[29] American Public Health Association (2012) Standard Methods for Examination of Water and Waste Water. 22nd Edition, American Public Health Association Press, Washington DC. 
[30] Water Watch Australia (2002) National Technical Manual. Module 4: Physical and Chemical Parameters. Water Watch Australia Steering Committee Environment, Australia. http://www.waterwatch.org.au

[31] Trimmer, W. (1994) Estimating Water Flow Rates. Oregon State University Website. http://extension.oregonstate.edu/catalog/pdf/ec1369.pdf

[32] Merck (2011) Nitrite Test. Merck KGaA, Darmstadt. http://www.merck-chemicals.com/colorimetric-test-kits

[33] Merck (2011) Phosphate Test: For the Determination of Orthophosphate. Merck KGaA, Darmstadt. http://www.merck-chemicals.com/colorimetric-test-kits

[34] Olajire, A.A. and Imeokparia, F.E. (2001) Water Quality Assessment of Osun River: Studies on Inorganic Nutrients. Environmental Monitoring and Assessment, 69, 17-22. https://doi.org/10.1023/A:1010796410829

[35] Beadle, L.C. (1981) Inland Waters of Tropical Africa. 2nd Edition, Longman Group Limited, London.

[36] United Nations Environment Programme and World Health Organization (1996) Water Quality Monitoring: A Practical Guide to the Design and Implementation of Freshwater Quality Studies and Monitoring Programmes.

[37] Juma, N.G. (1998) The Pedosphere and Its Dynamics: A Systems Approach to Soil Science. Volume 1, Quality Color Press Incorperation, Edmonton.

[38] Hughes, R.H. and Hughes, J.S. (1992) A Directory of African Wetlands. IUCN, Gland, Cambridge; UNEP, Nairobi; WCMC, Cambridge.

[39] EPA (2001) Parameters of Water Quality: Interpretation and Standards. Environmental Protection Agency, Wexford. https://www.epa.ie/pubs/advice/water/quality/Water_Quality.pdf

[40] COWI (2010) Operationalisation of Catchment-Based Water Resources Management. Ministry of Water and Environment, Directorate of Water Resources Management, September 2010, Kampala Uganda.

[41] Trivede, P., Bajpai, A. and Thareja, S. (2010) Comparative Study of Seasonal Variations in Physico-Chemical Characteristics in Drinking Water Quality of Kanpur, India With Reference to 200 MLD Filteration Plant and Groundwater. Natural Sciences, 8, 11-17.

[42] Bot, A. and Benites, J. (2005) The Importance of Soil Organic Matter Key to drought-Resistant Soil and Sustained Food and Production. FAO Soils Bulletin 80, FAO, Rome.

[43] Vega, M., Pardo, R., Barrado, E. and Debàn, L. (1998) Assessment of Seasonal and Polluting Effects on the Quality of River Water by Exploratory Data Analysis. Water Research, 32, 3581-3592.

[44] Gibb, A. (1984) A Review of the Hydrology of Lake Victoria and the Victoria Nile. Institute of Hydrology, Wallingford. http://nora.nerc.ac.uk/507639/1/N507639CR.pdf

[45] Twongo, T., Bugenyi, F.W.B. and Wanda, F. (1995) The Potential for Further Proliferation of Water Hyacinth in Lakes Victoria, Kyoga and Kwania and Some Urgent Aspects for Research. African Journal of Tropical Hydrobiology and Fisheries, 6, 1-10.

[46] Vyas, V.G., Hassan, M.M., Vindhani, S.I., Parmar, H.J. and Bhalani, V.M. (2015) Physicochemical and Microbiological Assessment of Drinking Water from Different Sources in Junagadh City, India. American Journal of Microbiological Research, 3, 148-154. 
[47] Kristensen, E., Ahmed, S.I. and Devol, A.H. (1995) Aerobic and Anaerobic Decomposition of Organic Matter in Marine Sediment: Which Is Fastest? Limnology and Oceanography, 40, 1430-1437. https://doi.org/10.4319/lo.1995.40.8.1430

[48] Lukubye, B. and Andama, M. (2017) Physico-Chemical Quality of Selected Drinking Water Sources in Mbarara Municipality, Uganda. Journal of Water Resource and Protection, 9, 707-722. https://doi.org/10.4236/jwarp.2017.97047

[49] Wetzel, R.G. (2001) Limnology: Lake and River Ecosystem. 3rd Edition, Academic Press, San Diego.

[50] Tenagne, A.W. (2009) The Impact of Urban Storm Water Runoff and Domestic Waste Effluent on Water Quality of Lake Tana and Local Groundwater near the City of Bahir Dar, Ethiopia. M.Sc. Thesis, Cornell University, New York.

[51] Nriagu, J. (1992) Toxic Metal Pollution in Africa. The Science of the Total Environment, 121, 1-37.

[52] Lavelle, P. and Spain, A.V. (2001) Soil Ecology. Kluwer Academic Publishers, New York. https://doi.org/10.1007/978-94-017-5279-4

[53] Breeuwsma, A. (1992) Phosphorus Fertilization and Environmental Effects in Neitherlands and Po Region, Italy. DLO the Winand Staring Centre, Wageningen. 